\title{
Does the Kyoto Protocol as an International Environmental Policy Promote Forest Carbon Sinks?
}

\author{
Jiamin Ge, Xiamen University, China \\ Boqiang Lin, Xiamen University, China*
}

\begin{abstract}
Under the background of carbon neutrality, the carbon sequestration of forest ecosystems is an important way to mitigate climate change. Forests could not only protect the environment but also be an important industry for economic development. As an international climate policy that first recognized the role of forest carbon sinks on climate change, the question becomes, has the Kyoto Protocol promoted the development of forest carbon sinks in contracting parties? To explore this, data of forests can be obtained at the national level. Hence, data of economic, social, polity, and climate in 147 countries is also collected. The generalized synthetic control method is adopted. The results show that the policy effect of the Kyoto Protocol was obvious and significant. Moreover, the effect was more significant after the enforcement in 2005. Especially after the first commitment period, the policy effect of the second period is more obvious. Some policy implications are drawn.
\end{abstract}

\section{KEYWORDS}

Forest Carbon Sinks, Kyoto Protocol, Policy Effectsynthetic Control Method

\section{INTRODUCTION}

Forest is an important ecological and economic resource that is an effective way to achieve green economic development. Forests are the largest carbon pool in terrestrial ecosystems and play an irreplaceable role in carbon sequestration. The development of forestry can bring economic income to areas rich in forest resources. Forest carbon sinks can realize its economic value through its contribution to climate change through the carbon trading market and forest tourism also bring benefit (Song et al., 2020). Under the background of carbon neutrality, the role of forest carbon sinks has gradually received widespread attention. Kyoto Protocol is the first international policy to recognize the role of forest carbon sinks on climate change, whether it has promoted the development of forest carbon sinks is worth studying. With the advent of the big data era, more information can be obtained, thus realizing effective management of forest resources. Big data analytics outperform traditional statistical approaches (Gholami, Nishant, \& Emrouznejad, 2021). The identification of the policy effect on the development of forest carbon sinks needs to be compared with the gap between 


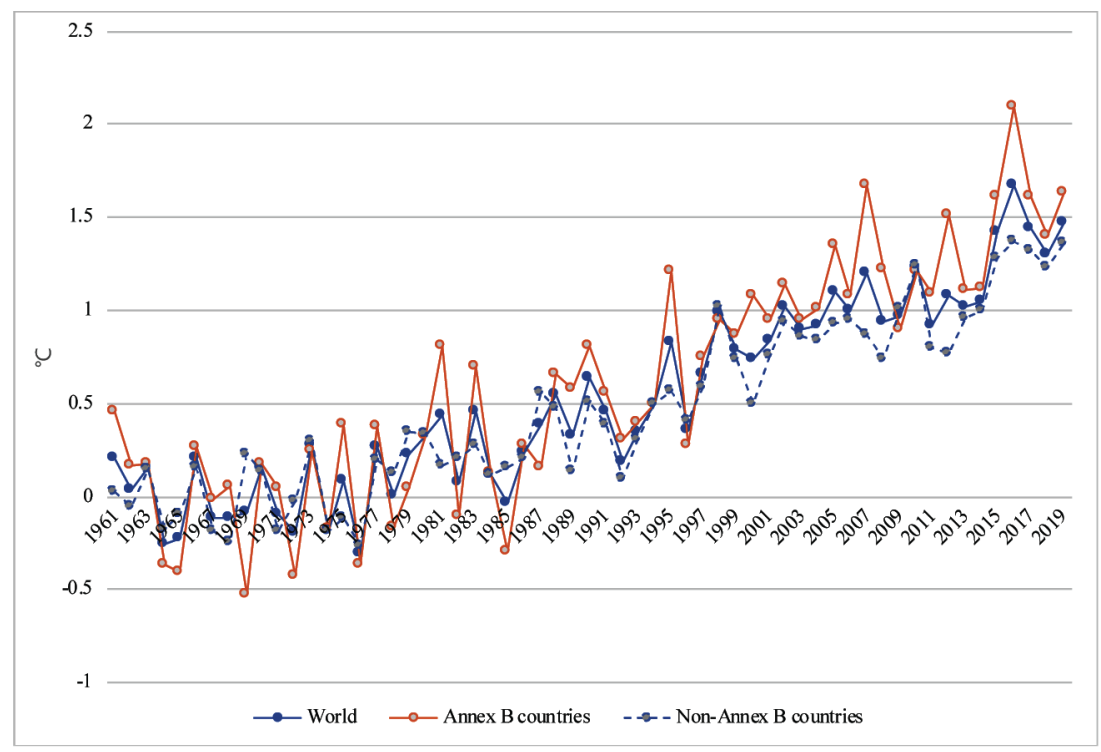

the countries that have signed the protocol and the countries that have not. The data-driven fitting method can effectively construct counterfactuals and identify the size of the policy effect. Hence, it offers new opportunities for this study.

From a data perspective, it is easy to understand climate change. Figure 1 shows the trend of global temperature changes from 1961 to 2019. It could be found that the temperature change is on the rise, and the temperature rise is more evident. There was still a drop before the 1990s. Since the 1990s, the temperature rise has become more and more obvious. Besides, it could be seen that Annex $\mathrm{B}$ countries have a larger temperature change range than Non-Annex B countries. Among them, Annex B countries refer to industrialized countries that signed the Kyoto Protocol. The Kyoto Protocol had formulated emission reduction tasks for the Annex B countries that have signed the Protocol. In the Kyoto Protocol, greenhouse gas emissions are calculated based on net emissions, that is, the amount of carbon dioxide absorbed by forests should be subtracted from the country's actual emissions.

Chen et al. (2020) believed that the relationship between technological progress and carbon emissions is complex and depends on changes in environmental technology and production technology. However, there are two main ways of technological progress to mitigate climate change: one is to reduce carbon sources, that is, to reduce greenhouse gas emissions from human activities; the other is to increase carbon sinks. Forests can absorb and fix carbon dioxide within a certain time which is the forest carbon sink. The Kyoto Protocol recognized the contribution of forest carbon sinks to climate change for the first time in international policies and required the strengthening of sustainable forest management and vegetation protection. And the Bali Road Map determined an action to reduce emissions in developing countries, that is, reducing emissions caused by deforestation and forest degradation (REDD). Then, the Copenhagen Agreement proposed REDD+, and the meaning of plus is to improve forest carbon sinks. To study whether the Kyoto Protocol promoted the development of forest carbon sinks, forest carbon sinks in Annex B countries and non-Annex B countries can be compared.

Considering the problem explored, the structure of this paper is as follows: The second section is a literature review to make a theoretical analysis and introduction of the contributions. The third part introduces the method and the indicators adopted by this study. The fourth section shows the results 
and discussions, the fifth part is the robustness test and the last section summarizes the conclusions and proposes policy implications.

\section{LITERATURE REVIEW}

The literature is summarized from two aspects. The first is the related research on the Kyoto Protocol, mainly including its positive and negative evaluations, and the second is the relationship between the Kyoto Protocol and forest carbon sinks. It would be a theoretical analysis of whether the Kyoto Protocol would affect forest carbon sinks.

\section{The Study of the Kyoto Protocol}

Since the Kyoto Protocol, the high economic cost of climate policy has caused heated debate (Viguier, Babiker, \& Reilly, 2003; Golusin \& Munitlak Ivanovic, 2011). Kuosmanen, Zhou, \& Dai (2020) evaluated the emission reduction costs in 28 OECD countries which were far lower than the forecast in the late 1990s. This result called for more ambitious climate change mitigation strategies in the future. Miyamoto \& Takeuchi (2019) examined the impact of the Kyoto Protocol on the international spread of renewable energy technologies and agreed with the importance of the climate change agreement for international technology dissemination. Mele, Paglialunga, \& Sforna (2020) also showed that the Kyoto Protocol had a positive impact on the cost-effectiveness of renewable energy projects and promoted environmental sustainability policy actions. Kuriyama \& Abe (2018) found that the Kyoto Protocol has brought the world an actual emission reduction and proposed two important lessons learned from the Kyoto Protocol. One is that insufficient emission caps did not provide any mitigation incentives and the other one is it is more important to design international cooperation mechanisms.

However, the effectiveness of the Kyoto protocol is controversial. Maamoun (2019) and Almer \& Winkler (2017) addressed its effectiveness by comparing emissions of industrialized countries with the counterfactual scenario in the absence of protocol. Copeland \& Taylor (2005) proposed when international emissions permit trading did occur, it may worsen both parties to the trade and increase global emissions. Ju et al. (2021) conducted comparative studies on international climate policies and believed that the Kyoto Protocol would allow developing countries with large populations to generate more emissions. Furthermore, Nguyen \& Phan (2020) found that the approval of the Kyoto Protocol had led to increasing carbon risks for heavy-carbon emitting companies, leading to higher risks of financial distress and prompting companies to reduce their financial leverage. In addition, Nguyen \& Shi (2021) studied the increased external risks of signing the Kyoto Protocol to greenhouse gas emitters, and the stock market's response to emitter bank loan announcements has increased significantly.

Moreover, van Vuuren et al. (2006) found the size of supplementary benefits depends on how to implement the mechanism flexibly and achieve the goal of the Kyoto Protocol. Therefore, the policy effect of the Kyoto Protocol is inconclusive, whether it has an impact on the forest carbon sinks can be further explored.

\section{Kyoto Protocol and Forest Carbon Sinks}

Ecological balance and carbon sink economy receive more and more attention in coping with global warming. Wu et al. (2020) estimated the potential benefits of the carbon sink economy. And there is an interaction between forest carbon sinks and climate change (Case et al., 2021). The Kyoto Protocol requires reporting changes in net carbon stocks and man-made emissions, including forest-related changes. As forests are important carbon sinks, Aydin \& Gençay (2011) assessed whether Turkey’s forest legislation meets the goal of the Kyoto Protocol, which cannot currently be considered sufficient to fulfil the obligations under the Kyoto Protocol. However, Liu et al. (2016) analyzed the greenhouse gas emissions of parties' different sectors in the first commitment period of the Kyoto Protocol which showed that agriculture and LULUCF contributed to the reduction. The expansion of forests into 
the original agricultural land plays an important role in generating carbon sinks that are eligible for afforestation activities in the carbon accounting framework of the Kyoto Protocol (Alivernini et al., 2016). Through data analysis, Zhang (2011) showed that forest management credits have made a significant contribution to the Kyoto Protocol parties' targets in the first commitment period. And Rahman \& Kirkman (2015) studied the cost of certified emission reductions which is much higher than that of afforestation and reforestation.

The research of Chen et al. (2020) emphasized ecological carbon absorption is of great significance to climate change. Climate change policies should pay more attention to areas with rich primary productivity. A forest carbon sink is an important mechanism of climate change and forest management strategies can contribute to broader societal economic and environmental goals (Daigneault, Sohngen, \& Sedjo, 2020; Daigneault \& Favero, 2021). However, the priority of different forest management measures would have an impact on the forest ecosystem (Shapiro et al., 2021). Besides, a reliable set of data, including all carbon pools, should be established to assess the scale of possible options. The data of forest inventories become more and more important for forest biodiversity assessment (Heym et al., 2021). Also, Bertram (2010) analyzed how the regulations on forests apply to ocean carbon sinks.

It can be found that the forest has played a positive role in fulfilling the emission reduction target which is proposed by Kyoto Protocol and the protocol also affects the development of forest carbon sink. Whether there is a policy effect and what the size of the policy effect is, this research attempts to answer this question next. Therefore, the innovations of this study include the following two points. Firstly, many studies focus on the evaluation of the policy effects of reducing carbon emissions. However, the carbon sequestration function of the forest should not be ignored. This study tries to explore whether the Kyoto Protocol, as an international environmental policy, has similar policy effects for forest carbon sinks. Secondly, the synthetic control method is used to study the problem. To make the research more rigorous, in terms of data, indicators of the economy, society, polity, and climate conditions in 147 countries around the world are collected. The country list is determined mainly based on the intersection of different database countries and the availability of data. Among them, there are 30 countries in the treatment group and 117 countries in the control group. The number of samples collected is relatively large, and the "counterfactual" outcome variables can be effectively synthesized through the synthetic control method.

\section{METHOD AND DATA}

\section{Generalized Synthetic Control Method}

For the method of studying policy effects, many scholars usually use the difference-in-difference method to explore (Vollenweider, 2013; Grunewald \& Martinez, 2016). Regarding the Kyoto Protocol, non-Annex B countries had no binding greenhouse gas emission targets. Therefore, they are natural candidates for the control group. However, in terms of national development, there is a clear selection bias: Annex B countries roughly cover countries with significant industrial development in the 1990s. Therefore, non-Annex B countries have significant differences in the characteristics of relevant countries. Moreover, Annex B countries can achieve the emission targets through domestic reductions or the use of three flexible mechanisms: Emissions Trading, Joint Implementation and Clean Development Mechanism (CDM). CDM contains projects of forest carbon sink and it encourages Annex B countries to cooperate with non-Annex B countries. Although the Kyoto Protocol clearly stated the flexible mechanisms should only be used as a supplement to domestic emission reduction efforts, it may blur the distinction between countries and untreated countries. Then, the emission reductions of non-Annex B countries can be included in supporting Annex B countries. Therefore, non-Annex B countries may also be affected by the Kyoto Protocol, even if they do not have any direct emission reduction obligations. The Differences-In-Differences (DID) approach cannot be used directly since the research results may be biased. 
To solve the above problems, the synthetic control method (SCM) proposed by Abadie and Gardeazabal (2003) constructed facts for each treated country by assigning a weighted value to the untreated country, so that the actual country and its synthetic country overlap as much as possible in terms of forest carbon sinks and all other relevant characteristics. Therefore, the idea of the synthetic control method is to use data to construct a synthetic control group. It can effectively reduce the subjectivity of selecting a control group and ensure the correlation between the treated group and the control group. Increasing samples of the synthetic control group to make the synthetic results more suitable for the actual country, thereby overcoming the above two problems. Moreover, the synthetic control method can get specific results for each year and each country. Besides, Almer \& Winkler (2017) pointed out that SCM allows us to resolve the violation of the common trend assumption by rebalancing and controlling the treated indicator and other important predictive indicators selected in the processing.

In this study, since there are multiple treated countries, the process of the generalized synthetic control method proposed by $\mathrm{Xu}$ (2017) was adopted. This method can not only relax the assumption of DID but also combine the linear fixed effect model with the methods proposed by Abadie, Diamond and Hainmueller (2010) in a simple framework. It is based on a linear interactive fixed-effects model that uses control group information to estimate counterfactuals for each unit processed. This model contains unit-specific intercepts that interact with time-varying coefficients. This method has several advantages. First, it allows processing to be associated with the unobserved unit and time heterogeneity under reasonable modeling assumptions. Second, the comprehensive control method is extended to multiple processing units and variable processing cycles, which improves efficiency and interpretability. Third, given the built-in cross-validation program, it avoids canonical search and is easy to implement. However, the GSCM is similar to the idea of the SCM.

Based on the assumption of the GSCM, that the treated and control countries have to be affected by the same set of factors which are observed covariates $X_{i t}$ and unobserved common factors $f_{t}$. $X_{i t}$ is a $\left(\mathrm{k}^{*} 1\right)$ vector and $f_{t}=\left[f_{1 t}, \ldots, f_{r t}\right]^{\prime}$ which is an $(\mathrm{r} \times 1)$ vector. The actual forest carbon sink $Y_{i t}$ of country $i$ in period $t$ can be expressed as:

$Y_{i t}=\alpha_{i t} D_{i t}+X_{i t}^{\prime} \beta+\lambda_{i}^{\prime} f_{t}+\epsilon_{i t}$

Assuming $T_{0}\left(1 \leq T_{0} \leq T\right)$ denotes the number of periods before policy intervention. Let $D_{i t}$ represent the implementation of policies in each country. If country $i$ is in the state of policy implementation in $t$ period, then $D_{i t}=1$, otherwise $D_{i t}=0$. Since there are only treated countries, it is in the policy implementation state after $T_{0} . Y_{i t}^{0}$ represents the forest carbon sink of country $i$ in period $t$ if no policy is implemented and $Y_{i t}^{1}$ represents the forest carbon sinks of the country if the policy was implemented. Therefore, the difference between $Y_{i t}^{0}$ and $Y_{i t}^{1}$ is the policy effect of country $i$ at time $t$, and $\alpha_{i t}=Y_{i t}^{1}-Y_{i t}^{0}$.

Now our goal is to estimate all the $\alpha_{i t}$. For $t>T_{0}$ :

$A T T_{\left(t, t>T_{0}\right)}=\frac{1}{N_{t r}} \sum_{i \in \tau}\left[Y_{i t}^{1}-Y_{i t}^{0}\right]=\frac{1}{N_{t r}} \sum_{i \in \tau} \alpha_{i t}$ 
where ATT is average treatment effect on the treated, $N_{t r}$ is the number of the treated countries and $\tau$ is a set of the treatment groups. Because $Y_{i t}^{1}$ is the actual value of forest carbon sinks, only $Y_{i t}^{0}$ needs to be estimated to estimate $\alpha_{i t}$. The estimator of $Y_{i t}^{0}$ is:

$\widehat{Y_{i t}^{0}}=x_{i t}^{\prime} \hat{\beta}+\widehat{\lambda}_{i}^{\prime} \widehat{f}_{t}, i \in \tau, t>T_{0}$

Therefore $\hat{\beta}, \widehat{\lambda_{i}}, \widehat{f}_{t}$ can be estimated by the following step:

Step 1: Obtain a fixed number $r$ of unobserved common factors by estimating an interactive fixed effects model using control group data. For the control countries, the actual forest carbon sink could be expressed as $Y_{i t}=X_{i t}^{\prime} \beta+\lambda_{i}^{\prime} f_{t}+\epsilon_{i t}$, therefore, we can combine all control countries together as the equation is:

$$
Y_{c o}=X_{c o} \beta+F \Lambda_{c o}^{\prime}+\varepsilon_{c o}
$$

$$
\begin{gathered}
\left(\hat{\beta}, \hat{F}, \widehat{\Lambda_{c o}}\right)=\underset{\hat{\beta}, \hat{F}, \widehat{\Lambda}_{c o}}{\arg \min } \sum\left(\tilde{Y}_{i}-\tilde{X}_{i} \beta-\tilde{F} \tilde{\lambda}_{i}\right)^{\prime}\left(\tilde{Y}_{i}-\tilde{X}_{i} \beta-\tilde{F} \tilde{\lambda_{i}}\right) \\
\text { s.t. } \frac{\tilde{F}^{\prime} F}{T}=I_{r} \text { and }\left(\widetilde{\Lambda_{c o}^{\prime}} \widetilde{\Lambda_{c o}}\right)
\end{gathered}
$$

Step 2: Estimate the factor loadings of the predicted treatments in pretreatment periods:

$$
\begin{gathered}
\widehat{\lambda_{i}}=\underset{\hat{\Lambda}_{i}}{\arg \min }\left(Y_{i}^{0}-X_{i}^{0} \hat{\beta}-\widehat{F^{0}} \tilde{\lambda}_{i}\right)^{\prime}\left(Y_{i}^{0}-X_{i}^{0} \hat{\beta}-\widehat{F^{0}} \tilde{\lambda}_{i}\right) \\
=\left(\widehat{F^{0}}, \widehat{F^{0}}\right)^{-1} \widehat{F^{0}}\left(\widehat{Y^{0}}-\widehat{X_{i}^{0}} \hat{\beta}\right), i \in \tau
\end{gathered}
$$

Then the mean square prediction error (MSPE) is caculated by given $\mathrm{r}$ :

$$
\operatorname{MSPE}(r)=\frac{\sum_{s=1}^{T_{0}} \sum_{i \in \tau} e_{i s}^{2}}{T_{0}}
$$

Step 3: $\mathrm{r}$ corresponding to the smallest MSPE is chosen to get $\hat{\beta}, \widehat{\lambda_{i}}, \widehat{f_{t}}$. Therefore, an estimator of ATT is $\overline{A T T_{\left(t, t>T_{0}\right)}}=\frac{1}{N_{t r}} \sum_{i \in \tau}\left[Y_{i t}^{1}-\widehat{Y_{i t}^{0}}\right]$. For more details about the model, Xu (2017) could be refered to. 


\section{Data Description}

The data from 147 countries is the intersection of countries from the list of different databases. The list of Annex B countries and donor pool countries is in the Appendix. Since the availability of data, the data of all variables are selected from 1990 to 2018.

The amount of forest carbon sinks is the increment of carbon storage during a certain time. The factors of the carbon sinks go through affecting carbon storage. Therefore, carbon storage is selected as the dependent variable which comes from the Global Forest Resources Assessment 2020. And the detailed data is treated by following Lin \& Ge (2020).

The composite indicators include political environment indicator which is Political right (Payne, 1995; Torras \& Boyce, 1998; Farzin \& Bond, 2006; Wen et al., 2016; Rios \& Gianmoena, 2018), social development indicator which is Life expectancy (Almer \& Winkler, 2017), economic development indicators which are GDP growth and GDP per capita (Buongiorno \& zhu, 2016; Lin \& Ge, 2019), industrial structure index which are Agriculture, forestry, and fish, value-added, Industry (including construction), value-added and Services, value-added (Almer \& Winkler, 2017; Lin \& Ge, 2020), population indicator which is Population growth (Almer \& Winkler, 2017), urbanization indicator which is the Urban population (Xu et al., 2016) and climate indicator which is Temperature change.

The Political right (Poli) is the democracy degree of different countries from Freedom House. This paper uses the average scores of political rights plus civil liberties as the scores of this indicator which is between 1 and 7. The lower scores represent higher democracy. Life expectancy $(L e)$ is selected as a society index which is from World Bank Development Indicators. And the GDP growth $(G D P g)$ and GDP per capita (GDPp, constant 2010 US\$) which is from the World Bank. Agriculture, forestry, and fish, value-added (Agri, \% of GDP), Industry (including construction), value added (Indu, $\%$ of GDP) and Services, value-added (Serv, \% of GDP) represent indicators of different industry structures in each country. This data is also derived from the World Bank database. The Population growth (Popg) and Urban population (Urbp, \% of the total population) are selected as population index and urbanization index respectively. The data comes from the World Bank database. Urban population is that people living in urban areas as defined by national statistical offices. Temperature change (Temc) in different countries comes from the Food and Agriculture Organization of the United Nations database. Descriptive statistics of variables are shown in Table 1.

Table 1. Descriptive statistics of variables

\begin{tabular}{|l|l|l|l|l|l|l|}
\hline \multicolumn{1}{|c|}{ Variable } & \multicolumn{1}{c|}{ N } & \multicolumn{1}{c|}{ Mean } & \multicolumn{1}{c|}{ SD } & \multicolumn{1}{c|}{ Median } & \multicolumn{1}{c|}{ Min } & \multicolumn{1}{c|}{ Max } \\
\hline Carbon Sink & 4060 & 71.98 & 43.81 & 63.13 & 4.28 & 288.70 \\
\hline Poli & 4060 & 3.46 & 1.86 & 3 & 1 & 7 \\
\hline Le & 4060 & 67.36 & 9.950 & 69.79 & 26.17 & 83.75 \\
\hline Agri & 4060 & 14.49 & 13.45 & 9.84 & 0.03 & 79.04 \\
\hline Indu & 4060 & 27.10 & 11.13 & 25.62 & 3.24 & 84.8 \\
\hline Serv & 4060 & 51.36 & 12.06 & 51.94 & 10.57 & 79.33 \\
\hline GDPg & 4060 & 3.70 & 5.05 & 3.91 & -64.05 & 57.82 \\
\hline GDPp (Thousand) & 4060 & 11 & 17 & 3.57 & 0.16 & 111.97 \\
\hline Popg & 4060 & 1.58 & 1.38 & 1.54 & -9.08 & 15.18 \\
\hline Urbp & 4060 & 52.82 & 22.79 & 53.42 & 5.42 & 100 \\
\hline Temc & 4060 & 0.82 & 0.54 & 0.79 & -1.25 & 2.77 \\
\hline
\end{tabular}




\section{RESULTS AND DISCUSSIONS}

The Kyoto Protocol was signed in 1997 which included 37 countries and the European Union. In 2005, countries were forced to implement emission reduction measurements. 2008-2012 is the first commitment period to achieve emission reduction targets. In December 2012, the Doha Supplementary Treaty designated 2013-2020 as the second emission reduction commitment period. Therefore, based on the existing data from 1990-2018, this article evaluates its policy effects in two stages. The first stage uses data from 1990-2012 to evaluate the policy effects of the first period of the Kyoto Protocol. Since the currently available data is only up to 2018 , it has not been possible to evaluate the policy effect after the completion of the entire second phase, but the policy implementation of the second phase has exceeded three-quarters, and it is possible to evaluate whether the current policy effect is generated. Therefore, the evaluation of the policy effects of the second phase is based on the data from 1990 to 2018. Besides, the policy intervention year was set as the signing year and the enforcement year.

\section{Overall Analysis}

The first stage mainly examines whether the Kyoto Protocol has a policy effect on the forest carbon sinks of Annex B countries that have signed the Protocol since the signing or enforcement of the Kyoto Protocol by 2012. This paper collects data from 147 countries, including 31 Annex B countries as the treated group, and 116 non-Annex B countries as the synthetic control group (The countries are list in Appendix). The results are shown in Table 2.

Table 2. The policy effect results of the first period

\begin{tabular}{|c|c|c|c|c|c|c|c|c|}
\hline & \multicolumn{4}{|c|}{1997 as treatment year } & \multicolumn{4}{|c|}{2005 as treatment year } \\
\hline & (1) & (2) & (3) & (4) & (5) & (6) & (7) & (8) \\
\hline ATT & $\begin{array}{l}0.5995 \\
(0.6373)\end{array}$ & $\begin{array}{l}8.404 * * * \\
(2.506)\end{array}$ & $\begin{array}{l}0.8057 \\
(0.5718)\end{array}$ & $\begin{array}{l}0.6566 \\
(0.5714)\end{array}$ & $\begin{array}{l}-0.8131 * * \\
(0.2565)\end{array}$ & $\begin{array}{l}1.394 * * * \\
(0.4055)\end{array}$ & $\begin{array}{l}-0.8894 * * \\
(0.2885)\end{array}$ & $\begin{array}{l}1.236 * * * \\
(0.2618)\end{array}$ \\
\hline Poli & $\begin{array}{l}-0.0696 \\
(0.0538)\end{array}$ & $\begin{array}{l}0.0275^{* *} \\
(0.0099)\end{array}$ & $\begin{array}{l}-0.0572 \\
(0.0517)\end{array}$ & $\begin{array}{l}-0.0199 \\
(0.0549)\end{array}$ & $\begin{array}{l}0.04 * * \\
(0.0131)\end{array}$ & $\begin{array}{l}-0.0035 \\
(0.0042)\end{array}$ & $\begin{array}{l}0.0434 * * * \\
(0.0129)\end{array}$ & $\begin{array}{l}-0.0006 \\
(0.0043)\end{array}$ \\
\hline Le & $\begin{array}{l}0.0268 \\
(0.0241)\end{array}$ & $\begin{array}{l}0.0315^{* *} \\
(0.0059)\end{array}$ & $\begin{array}{l}0.0458 * * \\
(0.0229)\end{array}$ & $\begin{array}{l}0.003 \\
(0.0451)\end{array}$ & $\begin{array}{l}0.1902 * * * \\
(0.0016)\end{array}$ & $\begin{array}{l}0.0441^{* * * *} \\
(0.0007)\end{array}$ & $\begin{array}{l}0.1867 * * * \\
(0.0015)\end{array}$ & $\begin{array}{l}-0.0025^{* *} \\
(0.001)\end{array}$ \\
\hline Agri & $\begin{array}{l}0.0013 \\
(0.0149)\end{array}$ & $\begin{array}{l}-0.0021 \\
(0.0019)\end{array}$ & $\begin{array}{l}0.003 \\
(0.015)\end{array}$ & $\begin{array}{l}0.01 \\
(0.0152)\end{array}$ & $\begin{array}{l}-0.0059 * * \\
(0.0027)\end{array}$ & $\begin{array}{l}-0.0012 \\
(0.0008)\end{array}$ & $\begin{array}{l}-0.0051 * \\
(0.0027)\end{array}$ & $\begin{array}{l}0.0000 \\
(0.0008)\end{array}$ \\
\hline Indu & $\begin{array}{l}0.0121 \\
(0.0134)\end{array}$ & $\begin{array}{l}-0.0025 \\
(0.0023)\end{array}$ & $\begin{array}{l}0.0128 \\
(0.0134)\end{array}$ & $\begin{array}{l}0.0192 \\
(0.0139)\end{array}$ & $\begin{array}{l}0.0022 \\
(0.0026)\end{array}$ & $\begin{array}{l}-0.0023 * * * \\
(0.0008)\end{array}$ & $\begin{array}{l}0.0012 \\
(0.0027)\end{array}$ & $\begin{array}{l}-0.003 * * * \\
(0.0008)\end{array}$ \\
\hline Serv & $\begin{array}{l}0.0031 \\
(0.0136)\end{array}$ & $\begin{array}{l}-0.0001 \\
(0.002)\end{array}$ & $\begin{array}{l}0.0026 \\
(0.0137)\end{array}$ & $\begin{array}{l}0.0073 \\
(0.0134)\end{array}$ & $\begin{array}{l}-0.0077 * * \\
(0.0029)\end{array}$ & $\begin{array}{l}-0.0005 \\
(0.0008)\end{array}$ & $\begin{array}{l}-0.0074 * * * \\
(0.0028)\end{array}$ & $\begin{array}{l}0.0003 \\
(0.0008)\end{array}$ \\
\hline GDPg & $\begin{array}{l}0.0108 * * \\
(0.004)\end{array}$ & $\begin{array}{l}-0.0012 * * \\
(0.0005)\end{array}$ & $\begin{array}{l}0.0107 * * \\
(0.0041)\end{array}$ & $\begin{array}{l}0.0069 \\
(0.004)\end{array}$ & $\begin{array}{l}0.0055^{* * * *} \\
(0.0011)\end{array}$ & $\begin{array}{l}-0.0014^{* * * *} \\
(0.0002)\end{array}$ & $\begin{array}{l}0.0049 * * * \\
(0.0011)\end{array}$ & $\begin{array}{l}-0.0018^{* * *} \\
(0.0003)\end{array}$ \\
\hline GDPp & $\begin{array}{l}-0.0002 * * * \\
(0.0000)\end{array}$ & $\begin{array}{l}0.0001^{* * * *} \\
(0.0000)\end{array}$ & $\begin{array}{l}-0.0002 * * * \\
(0.0000)\end{array}$ & $\begin{array}{l}0.0000 \\
(0.0001)\end{array}$ & $\begin{array}{l}-0.0004 * * * \\
(0.0000)\end{array}$ & $\begin{array}{l}0.0001 * * * \\
(0.0000)\end{array}$ & $\begin{array}{l}-0.0004 * * * \\
(0.0000)\end{array}$ & $\begin{array}{l}0.0001^{* * * *} \\
(0.0000)\end{array}$ \\
\hline Popg & $\begin{array}{l}-0.027 \\
(0.044)\end{array}$ & $\begin{array}{l}-0.0168^{*} \\
(0.0113)\end{array}$ & $\begin{array}{l}-0.0226 \\
(0.0435)\end{array}$ & $\begin{array}{l}-0.0264 \\
(0.0439)\end{array}$ & $\begin{array}{l}-0.0248 \\
(0.0151)\end{array}$ & $\begin{array}{l}-0.0192 * * * \\
(0.003)\end{array}$ & $\begin{array}{l}-0.0237^{*} \\
(0.0135)\end{array}$ & $\begin{array}{l}-0.018 * * * \\
(0.0034)\end{array}$ \\
\hline Urbp & $\begin{array}{l}0.1442 * * * \\
(0.0071)\end{array}$ & $\begin{array}{l}0.0418^{* * * *} \\
(0.0031)\end{array}$ & $\begin{array}{l}0.1428^{* * * *} \\
(0.0063)\end{array}$ & $\begin{array}{l}-0.0919 \\
(0.0622)\end{array}$ & $\begin{array}{l}0.1507 * * * \\
(0.0005)\end{array}$ & $\begin{array}{l}0.0376^{* * * *} \\
(0.0005)\end{array}$ & $\begin{array}{l}0.1539 * * * \\
(0.0005)\end{array}$ & $\begin{array}{l}-0.063 * * * \\
(0.0006)\end{array}$ \\
\hline Temc & $\begin{array}{l}0.0817 * * \\
(0.0452)\end{array}$ & $\begin{array}{l}-0.0078 \\
(0.0101)\end{array}$ & $\begin{array}{l}0.0527 \\
(0.0525)\end{array}$ & $\begin{array}{l}0.0222 \\
(0.0456)\end{array}$ & $\begin{array}{l}-0.0056 \\
(0.0152)\end{array}$ & $\begin{array}{l}0.0008 \\
(0.0032)\end{array}$ & $\begin{array}{l}-0.0137 \\
(0.0165)\end{array}$ & $\begin{array}{l}-0.0104 * * \\
(0.0041)\end{array}$ \\
\hline Country fixed effect & No & Yes & No & Yes & No & Yes & No & Yes \\
\hline Time fixed effect & No & No & Yes & Yes & No & No & Yes & Yes \\
\hline MSPE & 0.0393 & 0.0024 & 0.0398 & 0.0023 & 0.1351 & 0.0037 & 0.132 & 0.0056 \\
\hline
\end{tabular}

Note: Standard errors in parentheses, ${ }^{*} p<0.10,{ }^{* *} p<0.05,{ }^{* * *} p<0.01$ 
Among them, columns (1)-(4) are listed as the year of signing 1997 as the treatment year, 19901996 before the treatment, and 1998-2012 as the year after policy intervention. Columns (5)-(8) are listed as the year of enforcement in 2005 as the treatment year, 1990-2004 before the treatment, and 2006-2012 as the year after policy intervention. The four columns correspond to different fixed effects, namely, no fixed effect, country fixed effect, time fixed effect, and two-way fixed effect. According to the MSPE screening of more suitable model results, whether 1997 or 2005 is set as the year of policy intervention, the MSPE values of the fixed individual effect and two-way fixed effect model are smaller (column (2), column (4), column (6) and column (8)), indicating that these two models can better demonstrate the results of policy effects.

According to the above results, it can be found that when 1997 is set as the treatment year, the result of only fixed individual effects shows that the Kyoto Protocol's policy effect evaluation value is 8.404. When the individual and time are both fixed, the policy effect is not significant. When 2005 is set as the treatment year, the result of the individual fixed effect shows that the Kyoto Protocol's policy effect evaluation value is 1.394 . When the individual and time are both fixed, the policy effect result is 1.236 , and both evaluation results are very significant.

The second period is mainly examined the policy effect of 2013-2020 as the second commitment period. Due to the availability of data, the second phase effects are evaluated extending the policy implementation year to 2018. Since the four countries Canada, Japan, New Zealand and Russian Federation withdrew from the Kyoto Protocol in the second period, these countries were removed from the treated group, and some countries were added to the list of countries in Annex B, so these countries would also be removed from the synthetic control group. The treated group and the synthetic control group only retain countries that have been affected by the policy and those that have never been affected by the policy. Therefore, in this part of the policy effect evaluation, there are a total of 140 countries sample data, of which 113 countries are the synthetic control group, and the 27 Annex B countries are the treated group (The countries are list in Appendix). The evaluation of the policy effect in the second stage is also divided into two parts. The first is to set the year of signing in 1997 as the treatment year, the year before treatment from 1990 to 1996, and the year after policy intervention from 1998 to 2018. The second is to set the year of enforcement in 2005 as the treatment year, 19902004 are the years before the treatment, and 2006-2018 as the year after the policy intervention. The results are shown in Table 3.

The arrangement of each column is consistent with Table 2. According to the MSPE, the values of the individual fixed effect and two-way fixed effect models are smaller, indicating that these two models can better demonstrate the results of policy intervention effects. The result of individual fixed effects shows that the Kyoto Protocol's policy effect evaluation value is 8.282 when 1997 is set as the policy intervention year. When the individual and time are both fixed, the policy effect is 7.15. When 2005 is set as the year of policy intervention, the result of individual fixed effect and two-way fixed effect are 7.202 and 6.642, respectively. The policy effect of the second period is more significant for all.

Based on the results of the first period, if 1997 is taken as the treatment year, the policy effect is more significant, which shows that after the signing of the protocol in 1997, countries have begun to take measures such as forest protection. However, due to data limitations, when 1997 is set as the treatment year, there are fewer data in the year before the policy was implemented, and the effect of the country's synthesis process is poor. Therefore, the results with 2005 as the treatment year may be more accurate, and the data in the year before the policy intervention is more sufficient, which can better synthesize the countries of the experimental group. Moreover, from the estimated policy effect size, if 1997 is the treatment year, the policy effect of the Kyoto Protocol on forest carbon sinks would be overestimated. It is similar to the results of the second stage. Since the data are from 1990 to 2018, it would be better to set 2005 as the treatment year in the second phase. 1990 to 2004 are the years before the enforcement of the policy, and from 2006 to 2018 are after the enforcement of the policy. In the following year, 15 years of data were used to synthesize treated countries, and 
Table 3. The policy effect results of the second period

\begin{tabular}{|c|c|c|c|c|c|c|c|c|}
\hline & \multicolumn{4}{|c|}{1997 as treatment year } & \multicolumn{4}{|c|}{2004 as treatment year } \\
\hline & (1) & (2) & (3) & (4) & (5) & (6) & (7) & (8) \\
\hline ATT & $\begin{array}{l}-0.2369 \\
(1.638)\end{array}$ & $\begin{array}{l}8.282^{* *} \\
(3.05)\end{array}$ & $\begin{array}{l}8.52 \\
(5.01)\end{array}$ & $\begin{array}{l}7.15^{*} \\
(3.852)\end{array}$ & $\begin{array}{l}0.4079 \\
(0.6177)\end{array}$ & $\begin{array}{l}7.202 * * * \\
(1.148)\end{array}$ & $\begin{array}{l}0.3953 \\
(0.8)\end{array}$ & $\begin{array}{l}6.642^{* * * *} \\
(1.13)\end{array}$ \\
\hline Poli & $\begin{array}{l}-0.0278 \\
(0.0648)\end{array}$ & $\begin{array}{l}0.1043 * * \\
(0.0401)\end{array}$ & $\begin{array}{l}0.1037 * * * \\
(0.0327)\end{array}$ & $\begin{array}{l}0.0997 * * \\
(0.0396)\end{array}$ & $\begin{array}{l}0.1068 * * * \\
(0.0327)\end{array}$ & $\begin{array}{l}-0.013 * * \\
(0.0056)\end{array}$ & $\begin{array}{l}0.1037 * * \\
(0.0356)\end{array}$ & $\begin{array}{l}-0.0107^{*} \\
(0.0064)\end{array}$ \\
\hline $\mathrm{Le}$ & $\begin{array}{l}0.0096 \\
(0.0312)\end{array}$ & $\begin{array}{l}0.0198 \\
(0.0312)\end{array}$ & $\begin{array}{l}0.1901 * * * \\
(0.0172)\end{array}$ & $\begin{array}{l}-0.0215 \\
(0.034)\end{array}$ & $\begin{array}{l}0.1963^{* * *} \\
(0.0144)\end{array}$ & $\begin{array}{l}0.0517 * * * \\
(0.0013)\end{array}$ & $\begin{array}{l}0.1901 \text { *** } \\
(0.0217)\end{array}$ & $\begin{array}{l}0.0028 * * \\
(0.0028)\end{array}$ \\
\hline Agri & $\begin{array}{l}-0.0062 \\
(0.0176)\end{array}$ & $\begin{array}{l}0.0003 \\
(0.0097)\end{array}$ & $\begin{array}{l}0.0005 \\
(0.0088)\end{array}$ & $\begin{array}{l}0.001 \\
(0.01)\end{array}$ & $\begin{array}{l}-0.0004 \\
(0.0084)\end{array}$ & $\begin{array}{l}-0.0003 \\
(0.0014)\end{array}$ & $\begin{array}{l}0.0005 \\
(0.0087)\end{array}$ & $\begin{array}{l}0.0014 \\
(0.0014)\end{array}$ \\
\hline Indu & $\begin{array}{l}0.0018 \\
(0.0155)\end{array}$ & $\begin{array}{l}-0.0026 \\
(0.0092)\end{array}$ & $\begin{array}{l}-0.0008 \\
(0.008)\end{array}$ & $\begin{array}{l}-0.0007 \\
(0.0092)\end{array}$ & $\begin{array}{l}-0.0032 \\
(0.008)\end{array}$ & $\begin{array}{l}-0.003 * \\
(0.0015)\end{array}$ & $\begin{array}{l}-0.0008 \\
(0.0079)\end{array}$ & $\begin{array}{l}-0.003^{*} \\
(0.0015)\end{array}$ \\
\hline Serv & $\begin{array}{l}0.01 \\
(0.0155)\end{array}$ & $\begin{array}{l}-0.0006 \\
(0.0089)\end{array}$ & $\begin{array}{l}-0.0036 \\
(0.009)\end{array}$ & $\begin{array}{l}0.0003 \\
(0.009)\end{array}$ & $\begin{array}{l}-0.0046 \\
(0.0083)\end{array}$ & $\begin{array}{l}0.0004 \\
(0.0015)\end{array}$ & $\begin{array}{l}-0.0036 \\
(0.0088)\end{array}$ & $\begin{array}{l}0.001 \\
(0.0014)\end{array}$ \\
\hline GDPg & $\begin{array}{l}0.0143^{* * *} * \\
(0.0052)\end{array}$ & $\begin{array}{l}0.0001 \\
(0.0023)\end{array}$ & $\begin{array}{l}0.0026 \\
(0.0024)\end{array}$ & $\begin{array}{l}0.0007 \\
(0.0023)\end{array}$ & $\begin{array}{l}0.0028 \\
(0.0022)\end{array}$ & $\begin{array}{l}-0.0027 * * * \\
(0.0004)\end{array}$ & $\begin{array}{l}0.0026 \\
(0.0025)\end{array}$ & $\begin{array}{l}-0.0029 * * * \\
(0.0004)\end{array}$ \\
\hline GDPp & $\begin{array}{l}-0.0002 * * * \\
(0.0000)\end{array}$ & $\begin{array}{l}0.0000^{*} \\
(0.0000)\end{array}$ & $\begin{array}{l}-0.0001 * * * \\
(0.0000)\end{array}$ & $\begin{array}{l}0.0000 \\
(0.0000)\end{array}$ & $\begin{array}{l}-0.0001 * * * \\
(0.0000)\end{array}$ & $\begin{array}{l}0.0001 * * * \\
(0.0000)\end{array}$ & $\begin{array}{l}-0.0001 * * * \\
(0.0000)\end{array}$ & $\begin{array}{l}0.0002^{* * *} * \\
(0.0000)\end{array}$ \\
\hline Popg & $\begin{array}{l}-0.06 \\
(0.0505)\end{array}$ & $\begin{array}{l}-0.0123 \\
(0.031)\end{array}$ & $\begin{array}{l}-0.0487 * \\
(0.0318)\end{array}$ & $\begin{array}{l}-0.0087 \\
(0.0329)\end{array}$ & $\begin{array}{l}-0.0545^{*} \\
(0.0321)\end{array}$ & $\begin{array}{l}-0.0304 * * * \\
(0.0045)\end{array}$ & $\begin{array}{l}-0.0487 \\
(0.0316)\end{array}$ & $\begin{array}{l}-0.0281 * * * \\
(0.0053)\end{array}$ \\
\hline Urbp & $\begin{array}{l}0.1619 \text { *** } \\
(0.0087)\end{array}$ & $\begin{array}{l}0.0546 * * \\
(0.0245)\end{array}$ & $\begin{array}{l}0.1334 * * * \\
(0.0034)\end{array}$ & $\begin{array}{l}-0.0304 \\
(0.0381)\end{array}$ & $\begin{array}{l}0.1324 * * * \\
(0.0027)\end{array}$ & $\begin{array}{l}0.0117 * * * \\
(0.0008)\end{array}$ & $\begin{array}{l}0.1334 * * * \\
(0.0035)\end{array}$ & $\begin{array}{l}-0.0624 * * * \\
(0.0009)\end{array}$ \\
\hline Temc & $\begin{array}{l}0.1141^{* *} \\
(0.0549)\end{array}$ & $\begin{array}{l}0.032 \\
(0.0295)\end{array}$ & $\begin{array}{l}0.0166 \\
(0.0335)\end{array}$ & $\begin{array}{l}0.0009 \\
(0.0319)\end{array}$ & $\begin{array}{l}0.0472 * \\
(0.031)\end{array}$ & $\begin{array}{l}0.0176^{* * *} \\
(0.0081)\end{array}$ & $\begin{array}{l}0.0166 \\
(0.0345)\end{array}$ & $\begin{array}{l}-0.0045 \\
(0.0091)\end{array}$ \\
\hline Country fixed effect & No & Yes & No & Yes & No & Yes & No & Yes \\
\hline Time fixed effect & No & No & Yes & Yes & No & No & Yes & Yes \\
\hline MSPE & 0.0256 & 0.0025 & 0.0164 & 0.0015 & 0.0351 & 0.0106 & 0.0313 & 0.0159 \\
\hline
\end{tabular}

Note: Standard errors in parentheses, ${ }^{*} p<0.10,{ }^{* *} p<0.05,{ }^{* * *} p<0.01$

the policy effect of 13 years after the implementation of the policy was evaluated. Comparing the results of the policy effects of the first and second phases, it can be found that the Kyoto Protocol has a significant increase in its policy effects after the extension to the second phase. The magnitude of its effect in the second period is much larger than that of the first period although they are all positive which indicating that the Kyoto Protocol has a significant beneficial impact on the development of forest carbon sinks.

Furthermore, from the results of the columns (6) and (8) of Table 3 to analyze the results of other variables, political right, life expectation, the proportion of the secondary industry, GDP growth rate, GDP per capita, population growth rate and urbanization would have an impact on forest carbon sinks. Among them, the proportion of the secondary industry, GDP growth and population growth have negative impacts on forest carbon stocks. Secondary industries are generally high-pollution and high-emission industries. The higher the proportion of its output value, the greater the adverse impact on the environment. Environmental destruction and climate change are not conducive to the growth of forest carbon storage (Case et al., 2021). Economic growth and population growth are also the most important man-made factors in the current climate change problem, and its negative impact on the development of forest carbon sinks is very obvious. Other life expectations, GDP per capita and urban population proportion have positive impacts. The higher the expectation of life, the higher the requirements for the living environment and the country would pay more attention to environmental protection. At the same time, the proportion of the urban population has had a positive impact on it, since the use of firewood as fuel in rural areas would lead to a decrease in biomass. In 
this way, when the urban population increases, the forest carbon storage density would increase. In addition to GDP per capita, the impact of other indicators on forest carbon stocks is consistent with expectations. However, it is worth noting that political rights have positive and negative scenarios. The impact mechanism of the political right and economic development on forest carbon sinks was discussed more in-depth in the study of Lin \& Ge $(2020,2021)$.

\section{Trend Analysis}

After analyzing the overall policy effect of the Kyoto Protocol, further analysis of the time trend of the Kyoto Protocol's policy effect is carried out. The results of the policy effects of each year in the first stage are shown in Table 4.

Table 4. Policy effect results of each year in the first period

\begin{tabular}{|c|c|c|c|c|}
\hline & \multicolumn{2}{|c|}{1997 as treatment year } & \multicolumn{2}{|c|}{2004 as treatment year } \\
\hline 1998 & $\begin{array}{l}0.0738^{*} \\
(0.0414)\end{array}$ & $\begin{array}{l}-0.0396 \\
(0.0705)\end{array}$ & & \\
\hline 1999 & $\begin{array}{l}0.1149^{*} \\
(0.0699)\end{array}$ & $\begin{array}{l}-0.0656 \\
(0.1079)\end{array}$ & & \\
\hline 2000 & $\begin{array}{l}0.1546 \\
(0.0943)\end{array}$ & $\begin{array}{l}-0.1121 \\
(0.1566)\end{array}$ & & \\
\hline 2001 & $\begin{array}{l}1.641 * * * \\
(0.5228)\end{array}$ & $\begin{array}{l}0.0305 \\
(0.2000)\end{array}$ & & \\
\hline 2002 & $\begin{array}{l}3.155 * * * \\
(0.9769)\end{array}$ & $\begin{array}{l}0.1859 \\
(0.2723)\end{array}$ & & \\
\hline 2003 & $\begin{array}{l}4.669 * * * \\
(1.4279)\end{array}$ & $\begin{array}{l}0.3191 \\
(0.359)\end{array}$ & & \\
\hline 2004 & $\begin{array}{l}6.244 * * * \\
(1.9043)\end{array}$ & $\begin{array}{l}0.4706 \\
(0.4561)\end{array}$ & & \\
\hline 2005 & $\begin{array}{l}7.803 * * * \\
(2.384)\end{array}$ & $\begin{array}{l}0.6031 \\
(0.5563)\end{array}$ & $\begin{array}{l}0.0124 \\
(0.0427)\end{array}$ & $\begin{array}{l}-0.0062 \\
(0.0426)\end{array}$ \\
\hline 2006 & $\begin{array}{l}9.412 * * * \\
(2.8767)\end{array}$ & $\begin{array}{l}0.7209 \\
(0.6617)\end{array}$ & $\begin{array}{l}0.0357 \\
(0.0761)\end{array}$ & $\begin{array}{l}-0.0105 \\
(0.0727)\end{array}$ \\
\hline 2007 & $\begin{array}{l}11.06 * * * \\
(3.3849)\end{array}$ & $\begin{array}{l}0.8256 \\
(0.7778)\end{array}$ & $\begin{array}{l}0.0644 \\
(0.1235)\end{array}$ & $\begin{array}{l}-0.0198 \\
(0.1169)\end{array}$ \\
\hline 2008 & $\begin{array}{l}12.86^{* * * *} \\
(3.9095)\end{array}$ & $\begin{array}{l}0.955 \\
(0.8764)\end{array}$ & $\begin{array}{l}0.2934 * * \\
(0.1765)\end{array}$ & $\begin{array}{l}0.2088 \\
(0.1571)\end{array}$ \\
\hline 2009 & $\begin{array}{l}14.83^{* * * *} \\
(4.4546)\end{array}$ & $\begin{array}{l}1.0814 \\
(0.9764)\end{array}$ & $\begin{array}{l}0.6858 * * * \\
(0.2447)\end{array}$ & $\begin{array}{l}0.6421 * * * \\
(0.2097)\end{array}$ \\
\hline 2010 & $\begin{array}{l}16.61 * * * \\
(4.9748)\end{array}$ & $\begin{array}{l}1.1699 \\
(1.0876)\end{array}$ & $\begin{array}{l}0.8127 * * * \\
(0.2951)\end{array}$ & $\begin{array}{l}0.7166^{* * * *} \\
(0.252)\end{array}$ \\
\hline 2011 & $\begin{array}{l}17.98 * * * \\
(5.202)\end{array}$ & $\begin{array}{l}1.6033 \\
(1.1573)\end{array}$ & $\begin{array}{l}3.3214 * * * \\
(0.9361)\end{array}$ & $\begin{array}{l}2.9954 * * * \\
(0.5793)\end{array}$ \\
\hline 2012 & $\begin{array}{l}19.45 * * * \\
(5.4466)\end{array}$ & $\begin{array}{l}2.1006 * \\
(1.2296)\end{array}$ & $\begin{array}{l}5.9298 * * * \\
(1.6931)\end{array}$ & $\begin{array}{l}5.3612 * * * \\
(1.0241)\end{array}$ \\
\hline Country fixed effect & Yes & Yes & Yes & Yes \\
\hline Time fixed effect & No & Yes & No & Yes \\
\hline
\end{tabular}

Note: Standard errors in parentheses, ${ }^{*} p<0.10,{ }^{* *} p<0.05,{ }^{* * *} p<0.01$ 
According to the above selection with the smaller MSPE, only the country fixed effect and the two-way fixed effect models are showed in Table 4. Taking 1997 as the treatment year, the MSPE of the country fixed effect model is 0.0024 . The trend shows that it has had a significant positive impact on forest carbon stocks since 2001. The MSPE of the two-way fixed effects model is 0.0023 , and the results show that only in the last year of the first-phase commitment period, 2012, has a significant positive impact. Taking 2004 as the treatment year, the trend shows that since 2008, it has had a significant positive impact based on the results of the country fixed-effect model. The MSPE of the two-way fixed effects model is 0.0056 and it has had a significant positive impact since 2009. In summary, no matter what kind of situation, the Kyoto Protocol is conducive to the development of forest carbon sinks and began to produce policy effects during the first commitment period. Meanwhile, the results with 2005 as the year of policy intervention may be more accurate since the data is more sufficient, which can better synthesize the countries of the experimental group. If 1997 is the treatment year, the policy effect of the Kyoto Protocol on forest carbon sinks may be overestimated. However, the period of effect is still long, and the early policy effects are relatively small. Therefore, the trend of the policy effect after the extension to the second period is further observed and the results are shown in Table 5.

Similarly, the results of country and two-way fixed effect with the smallest MSPE were selected for analysis. Taking 1997 as the treatment year, the MSPE of both models are 0.0025 and 0.0015 . The result of the country fixed effect shows that since 2002, it has had a significant positive impact on global forest carbon sinks. And it has had a positive impact since 2011 based on the result of the two-way fixed-effect model. Taking 2004 as the treatment year, the MSPE of the country fixed effect model is 0.0106, and it shows that it has had a significant positive impact since 2009. The MSPE of the two-way fixed effects model is 0.0159 , and the result shows that since 2009 , it has begun to have a positive impact on global forest carbon stock.

According to the decomposition results and comparing between the first and second phases based on the magnitude of its effect, the policy effect of the Kyoto Protocol on forest carbon sinks has increased significantly over time after the extension to the second phase. After the commitment period of the first period, the policy effect of the second phase is more obvious. However, four countries of Canada, Japan, New Zealand and the Russian Federation withdrew from the Kyoto Protocol in the second period. Furthermore, the annual policy effects of these countries are decomposed in the first period. According to the results, the effects range from -0.06 to 1.29 in Canada, -0.09 to 1.89 in Japan, 0.003 to 2.18 in New Zealand and 0.06 to 4.60 in Russian Federation after enforcement. Effects on Canada, Japan and New Zealand are smaller than the results above. These three countries expressly opposed the Kyoto Protocol and proposed it can't help alleviate climate change after the first commitment period. Russia believed the United States, China and India were not included and withdrew the protocol in the second period. Although there are still some effects after the first stage in Russia based on the result.

\section{ROBUSTNESS TEST}

Since this research uses more sample countries as donor pools, it can better synthesize the treated countries, but whether the appearance of policy effects also be obtained by the synthetic process. This is a noteworthy issue, so all the countries are re-randomized in the donor pool to form a virtual treated group, and then use the same method to estimate and observe whether there is a significant policy effect. Besides, DID is used to estimate the policy effect again to explore whether it is similar to the result above. Therefore, the robustness test includes a placebo test and a comparative analysis of the DID results. 
Table 5. Policy effect results of each year in the second period

\begin{tabular}{|c|c|c|c|c|}
\hline & \multicolumn{2}{|c|}{1997 as treatment year } & \multicolumn{2}{|c|}{2004 as treatment year } \\
\hline 1998 & $\begin{array}{l}0.015 \\
(0.0645)\end{array}$ & $\begin{array}{l}0.0000 \\
(0.0728)\end{array}$ & & \\
\hline 1999 & $\begin{array}{l}0.0171 \\
(0.101)\end{array}$ & $\begin{array}{l}-0.0005 \\
(0.1191)\end{array}$ & & \\
\hline 2000 & $\begin{array}{l}0.0165 \\
(0.1454)\end{array}$ & $\begin{array}{l}-0.0031 \\
(0.1657)\end{array}$ & & \\
\hline 2001 & $\begin{array}{l}0.8536 \\
(0.4465)\end{array}$ & $\begin{array}{l}0.7203 \\
(0.543)\end{array}$ & & \\
\hline 2002 & $\begin{array}{l}1.7032 * \\
(0.7832)\end{array}$ & $\begin{array}{l}1.451 \\
(0.9613)\end{array}$ & & \\
\hline 2003 & $\begin{array}{l}2.5534 * \\
(1.1191)\end{array}$ & $\begin{array}{l}2.177 \\
(1.3805)\end{array}$ & & \\
\hline 2004 & $\begin{array}{l}3.4265^{*} \\
(1.4656)\end{array}$ & $\begin{array}{l}2.927 \\
(1.822)\end{array}$ & & \\
\hline 2005 & $\begin{array}{l}4.2892^{*} \\
(1.8237)\end{array}$ & $\begin{array}{l}3.665 \\
(2.2683)\end{array}$ & $\begin{array}{l}-0.0372 \\
(0.0584)\end{array}$ & $\begin{array}{l}-0.0642 \\
(0.0635)\end{array}$ \\
\hline 2006 & $\begin{array}{l}5.1782 * \\
(2.1927)\end{array}$ & $\begin{array}{l}4.422 \\
(2.7305)\end{array}$ & $\begin{array}{l}-0.0542 \\
(0.0984)\end{array}$ & $\begin{array}{l}-0.1193 \\
(0.1047)\end{array}$ \\
\hline 2007 & $\begin{array}{l}6.0665^{*} \\
(2.575)\end{array}$ & $\begin{array}{l}5.197 \\
(3.2158)\end{array}$ & $\begin{array}{l}-0.1237 \\
(0.1581)\end{array}$ & $\begin{array}{l}-0.233 \\
(0.1663)\end{array}$ \\
\hline 2008 & $\begin{array}{l}7.0877 * \\
(2.9925)\end{array}$ & $\begin{array}{l}6.061 \\
(3.7355)\end{array}$ & $\begin{array}{l}0.2367 \\
(0.2099)\end{array}$ & $\begin{array}{l}0.1101 \\
(0.2121)\end{array}$ \\
\hline 2009 & $\begin{array}{l}8.2248 * * \\
(3.4564)\end{array}$ & $\begin{array}{l}7.033 \\
(4.3013)\end{array}$ & $\begin{array}{l}0.8392 * * * \\
(0.2755)\end{array}$ & $\begin{array}{l}0.7413 * * \\
(0.2656)\end{array}$ \\
\hline 2010 & $\begin{array}{l}9.2391 * * \\
(3.869)\end{array}$ & $\begin{array}{l}7.859 \\
(4.8097)\end{array}$ & $\begin{array}{l}1.0071^{* * *} \\
(0.3351)\end{array}$ & $\begin{array}{l}0.8065^{* *} \\
(0.3166)\end{array}$ \\
\hline 2011 & $\begin{array}{l}10.6951 * * \\
(4.1922)\end{array}$ & $\begin{array}{l}9.19 * \\
(5.2551)\end{array}$ & $\begin{array}{l}3.3401 * * * \\
(0.7237)\end{array}$ & $\begin{array}{l}3.3001 * * * \\
(0.5504)\end{array}$ \\
\hline 2012 & $\begin{array}{l}12.2714 * * \\
(4.5555)\end{array}$ & $\begin{array}{l}10.6^{*} \\
(5.7414)\end{array}$ & $\begin{array}{l}5.857 * * * \\
(1.3036)\end{array}$ & $\begin{array}{l}5.9432 * * * \\
(0.9516)\end{array}$ \\
\hline 2013 & $\begin{array}{l}13.9059^{* * *} \\
(4.9337)\end{array}$ & $\begin{array}{l}12.05^{*} \\
(6.2459)\end{array}$ & $\begin{array}{l}8.3997 * * * \\
(1.8878)\end{array}$ & $\begin{array}{l}8.5951 * * * \\
(1.3712)\end{array}$ \\
\hline 3014 & $\begin{array}{l}15.5416^{* *} \\
(5.3335)\end{array}$ & $\begin{array}{l}13.55^{*} \\
(6.7809)\end{array}$ & $\begin{array}{l}10.919 * * * \\
(2.4739)\end{array}$ & $\begin{array}{l}11.2358^{* * * *} \\
(1.7914)\end{array}$ \\
\hline 2015 & $\begin{array}{l}17.299^{* * *} \\
(5.748)\end{array}$ & $\begin{array}{l}15.1^{*} \\
(7.3292)\end{array}$ & $\begin{array}{l}13.5322 * * * \\
(3.0454)\end{array}$ & $\begin{array}{l}13.8775^{* * * *} \\
(2.2021)\end{array}$ \\
\hline 2016 & $\begin{array}{l}18.0729 * * \\
(6.1025)\end{array}$ & $\begin{array}{l}15.68 * \\
(7.8181)\end{array}$ & $\begin{array}{l}17.1183^{* * *} \\
(3.1701)\end{array}$ & $\begin{array}{l}15.0125^{* * *} \\
(3.3753)\end{array}$ \\
\hline 2017 & $\begin{array}{l}18.539 * * \\
(6.3888)\end{array}$ & $\begin{array}{l}16.07 * \\
(8.1877)\end{array}$ & $\begin{array}{l}19.4211 * * * \\
(3.911)\end{array}$ & $\begin{array}{l}16.5832 * * * \\
(4.4099)\end{array}$ \\
\hline 2018 & $\begin{array}{l}18.9252^{* *} \\
(6.5979)\end{array}$ & $\begin{array}{l}16.4^{*} \\
(8.4548)\end{array}$ & $\begin{array}{l}20.3778 * * * \\
(4.3422)\end{array}$ & $\begin{array}{l}17.2051^{* *} \\
(4.8971)\end{array}$ \\
\hline Country fixed effect & Yes & Yes & Yes & Yes \\
\hline Time fixed effect & No & Yes & No & Yes \\
\hline
\end{tabular}

Note: Standard errors in parentheses, ${ }^{*} p<0.10,{ }^{* *} p<0.05,{ }^{* * *} p<0.01$ 
Table 6. The results of the placebo test

\begin{tabular}{|c|c|c|c|c|c|c|c|c|}
\hline & \multicolumn{8}{|c|}{ The first period } \\
\hline & \multicolumn{4}{|c|}{1997 as treatment year } & \multicolumn{4}{|c|}{2004 as treatment year } \\
\hline & Group 1 & Group 2 & Group 3 & Group 4 & Group 1 & Group 2 & Group 3 & Group 4 \\
\hline \multirow[t]{2}{*}{ ATT } & 2.102 & -8.097 & -6.014 & -0.9222 & -0.0182 & 0.1528 & 0.0566 & -0.0055 \\
\hline & $(1.261)$ & $(4.227)$ & (3.516) & $(1.902)$ & $(0.0786)$ & $(0.2847)$ & $(0.252)$ & $(0.106)$ \\
\hline \multirow[t]{4}{*}{ MSPE } & 0.0046 & 0.0006 & 0.0007 & 0.0023 & 0.0060 & 0.0007 & 0.0013 & 0.0061 \\
\hline & \multicolumn{8}{|c|}{ The second period } \\
\hline & \multicolumn{4}{|c|}{1997 as treatment year } & \multicolumn{4}{|c|}{2004 as treatment year } \\
\hline & Group 1 & Group 2 & Group 3 & Group 4 & Group 1 & Group 2 & Group 3 & Group 4 \\
\hline \multirow[t]{2}{*}{ ATT } & -1.377 & -1.927 & 2.354 & 0.4686 & 0.2985 & -0.0459 & 0.9081 & -0.3402 \\
\hline & (3.253) & $(2.578)$ & $(2.081)$ & $(1.656)$ & $(0.7812)$ & (1.337) & $(0.6846)$ & $(0.5255)$ \\
\hline MSPE & 0.0021 & 0.0038 & 0.0020 & 0.003 & 0.0026 & 0.0033 & 0.0042 & 0.0142 \\
\hline
\end{tabular}

Note: Standard errors in parentheses, ${ }^{*} p<0.10,{ }^{* *} p<0.05,{ }^{* * *} p<0.01$

\section{Placebo Test}

Randomly select several countries from the control group to replace the original policy countries, and use the GSCM method to estimate again. Since the alternative countries were randomly selected from the control group, they did not implement policy, so it is assumed that they have no policy effects. The purpose of the test is to examine the probability that alternative countries have policy effects and to test that such policy effects do not occur synthetically. The countries in the synthetic control group are devided into four groups, each of which is regarded as the 'treatment group', and the other three groups as the control group. Due to the differences in the country lists between the first and second stages, random grouping was carried out in the first and second stages, respectively. The method of random grouping is to sort the countries in ascending order of the abbreviated initials, and assign a random number to each country, and then re-sort it according to the size of the random number, and divide it into four different groups according to the order and assume that they are treated countries. The results of the placebo test are shown in Table 6.

According to the results in the above table, it can be found that the MSPE values are all small indicating that the model results are more accurate. However, the results of policy effects are not

Table 7. The results of the difference-in-difference model

\begin{tabular}{|c|c|c|c|c|c|c|c|c|}
\hline & \multicolumn{4}{|c|}{ The first period } & \multicolumn{4}{|c|}{ The second period } \\
\hline & \multicolumn{2}{|c|}{1997 as treatment year } & \multicolumn{2}{|c|}{ 2005as treatment year } & \multicolumn{2}{|c|}{1997 as treatment year } & \multicolumn{2}{|c|}{2005 as treatment year } \\
\hline & (1) & (2) & (3) & (4) & (5) & (6) & (7) & (8) \\
\hline ATT & $\begin{array}{l}2.8549 * * * \\
(0.2745)\end{array}$ & $\begin{array}{l}2.7227 \text { *** } \\
(0.2879)\end{array}$ & $\begin{array}{l}3.4889 * * * \\
(0.2745)\end{array}$ & $\begin{array}{l}3.3949 * * * \\
(0.2757)\end{array}$ & $\begin{array}{l}3.4362 * * * \\
(0.3420)\end{array}$ & $\begin{array}{l}3.6156^{* * * *} \\
(0.3599)\end{array}$ & $\begin{array}{l}5.1164 * * * \\
(0.2979)\end{array}$ & $\begin{array}{l}5.1276 \text { *** } \\
(0.3146)\end{array}$ \\
\hline Country fixed effect & Yes & Yes & Yes & Yes & Yes & Yes & Yes & Yes \\
\hline Time fixed effect & No & Yes & No & Yes & No & Yes & No & Yes \\
\hline $\mathrm{N}$ & 3381 & 3381 & 3381 & 3381 & 4060 & 4060 & 4060 & 4060 \\
\hline
\end{tabular}

Note: Standard errors in parentheses, ${ }^{*} p<0.10,{ }^{* *} p<0.05,{ }^{* * *} p<0.01$ 
significant based on GSCM method. It reveals the policy effect of the Kyoto Protocol on Annex B countries evaluated above is not synthesized, but real.

\section{Difference-in-Difference Model}

The difference-in-difference model is based on controlling the original change trend to obtain the treatment effect, which is an average treatment effect (SCM is a weighted average treatment effect). The policy effects obtained by the DID model are shown as supplementary and also as a robustness test. The results are shown in Table 7.

It can be found that the results corresponding to different fixed-effect DID methods are all significant. Comparing the size of the policy effect of both methods, the estimated result of the DID model in the first stage is larger than that of the GSCM method, while the result of the DID model in the second stage is smaller. According to the above analysis, there are some disadvantages of the DID model. This result can only be used as a supplement to prove that the result of the GSCM method is robust, and cannot be used as the result of the Kyoto Protocol's policy effect evaluation on forest carbon sinks.

Although the placebo test and DID model were used to test the robustness of the results, since the Kyoto Protocol allows flexible cooperation mechanisms between Annex B and non-Annex B countries, such as Clean Development Mechanism (CDM). CDM may have an impact on the development of forest carbon sinks in non-Annex B countries, GSCM method is adopted and countries in the control pool are expended, which may reduce some result bias. However, the bias still exists, so the top 5 CDM host countries (China, India, Brazil, Mexico, and Vietnam) are further removed from the control pool following Maamoun (2019). And the results obtained by the GSCM method are the same as the above results. Only the standard error has a small difference. Therefore, this is also the limitation of this study and the influence of CDM cannot be completely eliminated. The future work will explore more scientific methods to test the relevant policy effects of forest carbon sinks.

\section{CONCLUSION AND POLICY IMPLICATIONS}

Climate change is an issue that all countries in the world should face together. The Kyoto Protocol adopted in 1997 recognized the contribution of forest carbon sinks to the mitigation of climate warming for the first time in international environmental policies and required the strengthening of sustainable forest management. This article takes forest carbon sinks as the research object and uses carbon stock density indicators as the dependent variables to study the policy effects of the Kyoto Protocol. There are three conclusions that could be obtained:

1. From the analysis of the overall policy effect, the policy effect of the Kyoto Protocol on the first period of the Annex B countries is significantly positive. Among them, if 1997 is used as the treatment year, the policy effect is more obvious, which can be explained after signing the protocol in 1997, countries have begun to take measures such as forest protection. The effect of policy enforcement after 2005 is more significant. Combined with the commitment period of the second period, the policy implementation time is longer, and the policy effect is more obvious than that of the first period.

2. From the analysis of the policy effects trend, when 1997 is the treatment year, the country fixed effect model shows that it had a positive impact from 2001. The results of the two-way fixed effects model show that only in 2012, the last year of the first commitment period has a significant positive impact on forest carbon sinks. Taking 2004 as the treatment year, the results of the country fixed effect model shows that since 2008, it has had a significant positive impact. The results of the two-way fixed effect model show that since 2009, it has had a significant positive impact on global forest carbon sinks. In the second stage, there was a significant positive impact starting from 2002 when 1997 was used as the treatment year. The results of the two-way fixed effects 
model show that it has had a significant positive impact from 2011. Taking 2005 as the treatment year, the results of the country fixed effect model and two-way fixed effect model show that it has had positive impacts since 2009. Therefore, the policy effect was more significant after the mandatory entry into force in 2005. Especially after the commitment period of the first period, the policy effect of the second period is more obvious.

Besides, the placebo test in the robustness test confirmed that the policy effect is not a result synthesized by data simulation, and there is no significant effect in the randomly selected groups. The results of the difference-in-difference model show that the Kyoto Protocol has a positive policy effect which is consistent with the estimated results of the synthetic control method.

According to the conclusions, some policy implications could be drawn. First of all, as an international environmental policy, the Kyoto Protocol first proposed the role of forest ecosystems in fixing carbon dioxide and its role in promoting forest carbon sinks is very obvious based on the result. International environmental policy is still relatively obvious to countries that could call on all countries around the world to jointly address climate change and environmental protection. However, setting specific targets for the signed countries is much more significant. When International environmental policies require countries to implement specific actions, they are effective. Therefore, forest carbon sinks need to continue to be developed, relevant environmental policies or agreements with specific targets should be formulated. More authoritative international policies would have a more significant beneficial impact on the development of forest carbon sinks. Secondly, it can be found that the policy effect on forest carbon sinks began in the last year of the first phase. Based on the analysis of the first phase alone, the policy effect of the protocol on forest carbon sinks maybe not obvious. Of course, the Kyoto Protocol mainly aimed at carbon emission reduction, and the role of forest carbon sequestration is only one of them. But when the time is extended to the second stage, the policy effect is very significant. Therefore, when designing policies for forest carbon sinks, the length of policy implementation should be fully considered. For forests, the growth cycle of trees is relatively long, so that the regions or countries need to be given a longer period to make forest carbon storage have a significant increase. The policy design of forest carbon sinks needs to comprehensively consider 
the natural characteristics of forests. Thirdly, partition management may be efficient and it could through the division of forest areas into timber production areas, areas of carbon sinks, protected areas and other areas. It is important to make full use of information technology to manage global forest resources and use big data technology to manage forests in districts, then monitor changes of forest resources in real time.

\section{ACKNOWLEDGMENT}

This paper is supported by Fundamental Research Funds for the Central Universities: Policy and institution of clean, low carbon and sustainable energy system (Grant No. 20720191067).

\section{REFERENCES}

Abadie, A., Diamond, A., \& Hainmueller, J. (2010). Synthetic control methods for comparative case studies: Estimating the effect of California's tobacco control program. Journal of the American Statistical Association, 105(490), 493-505. doi:10.1198/jasa.2009.ap08746

Abadie, A., \& Gardeazabal, J. (2003). The economic costs of conflict: A case study of the Basque country. The American Economic Review, 93(1), 113-132. doi:10.1257/000282803321455188

Alivernini, A., Barbati, A., Merlini, P., Carbone, F., \& Corona, P. (2016). New forests and Kyoto Protocol carbon accounting: A case study in central Italy. Agriculture, Ecosystems \& Environment, 218, 58-65. doi:10.1016/j. agee.2015.11.006

Almer, C., \& Winkler, R. (2017). Analyzing the effectiveness of international environmental policies: The case of the Kyoto Protocol. Journal of Environmental Economics and Management, 82(December), 125-151.

Bertram, C. (2010). Ocean iron fertilization in the context of the Kyoto protocol and the post-Kyoto process. Energy Policy, 38(2), 1130-1139. doi:10.1016/j.enpol.2009.10.065

Buongiorno, J., Zhu, S., Zhang, D., Turner, J., \& Tomberlin, D. (2003). GFPM Structure and Formulation. Academic Press. doi:10.1016/B978-012141362-0/50004-2

Case, M. J., Johnson, B. G., Bartowitz, K. J., \& Hudiburg, T. W. (2021). Forests of the future: Climate change impacts and implications for carbon storage in the Pacific Northwest, USA. Forest Ecology and Management, 482 (October), 118886.

Chen, J., Gao, M., Mangla, S. K., Song, M., \& Wen, J. (2020). Effects of technological changes on China's carbon emissions. Technological Forecasting and Social Change, 153(February), 119938. doi:10.1016/j. techfore.2020.119938

Chen, J., Xu, C., Xie, Q., \& Song, M. (2020). Net primary productivity-based factors of China's carbon intensity: A regional perspective. Growth and Change, 51(4), 1727-1748. doi:10.1111/grow.12423

Copeland, B. R., \& Taylor, M. S. (2005). Free trade and global warming: A trade theory view of the Kyoto protocol. Journal of Environmental Economics and Management, 49(2), 205-234. doi:10.1016/j.jeem.2004.04.006

CoŞkun, A., \& Gençay, G. (2011). Kyoto Protocol and “deforestation”. A legal analysis on Turkish environment and forest legislation. Forest Policy and Economics, 13(5), 366-377.

Daigneault, A., \& Favero, A. (2021). Global forest management, carbon sequestration and bioenergy supply under alternative shared socioeconomic pathways. Land Use Policy, 103(January), 105302.

Daigneault, A. J., Sohngen, B. L., \& Sedjo, R. (2020). Carbon and market effects of U.S. forest taxation policy. Ecological Economics, 178, 106803. doi:10.1016/j.ecolecon.2020.106803

Farzin, Y. H., \& Bond, C. A. (2006). Democracy and environmental quality. Journal of Development Economics, 81(1), 213-235. doi:10.1016/j.jdeveco.2005.04.003 
Gholami, R., Nishant, R., \& Emrouznejad, A. (2021). Modeling Residential Energy Consumption. Journal of Global Information Management, 29(2), 166-193. doi:10.4018/JGIM.2021030109

Golusin, M., \& Munitlak Ivanovic, O. (2011). Kyoto Protocol implementation in Serbia as precognition of sustainable energetic and economic development. Energy Policy, 39(5), 2800-2807. doi:10.1016/j. enpol.2011.02.052

Grunewald, N., \& Martinez-Zarzoso, I. (2016). Did the Kyoto Protocol fail? An evaluation of the effect of the Kyoto Protocol on CO2 emissions. Environment and Development Economics, 21(1), 1-22. doi:10.1017/ S1355770X15000091

Heym, M., Uhl, E., Moshammer, R., Dieler, J., Stimm, K., \& Pretzsch, H. (2021). Utilising forest inventory data for biodiversity assessment. Ecological Indicators, 121, 107196. doi:10.1016/j.ecolind.2020.107196

Ju, B. G., Kim, M., Kim, S., \& Moreno-Ternero, J. D. (2021). Fair international protocols for the abatement of GHG emissions. Energy Economics, 94, 105091. doi:10.1016/j.eneco.2020.105091

Kuosmanen, T., Zhou, X., \& Dai, S. (2020). How much climate policy has cost for OECD countries? World Development, 125, 104681. doi:10.1016/j.worlddev.2019.104681

Kuriyama, A., \& Abe, N. (2018). Ex-post assessment of the Kyoto Protocol - quantification of CO2 mitigation impact in both Annex B and non-Annex B countries-. Applied Energy, 220(January), 286-295. doi:10.1016/j. apenergy.2018.03.025

Lin, B., \& Ge, J. (2019). Valued forest carbon sinks: How much emissions abatement costs could be reduced in China. Journal of Cleaner Production, 224, 455-464. doi:10.1016/j.jclepro.2019.03.221

Lin, B., \& Ge, J. (2020). How does institutional freedom affect global forest carbon sinks? The analysis of transfer paths. Resources, Conservation and Recycling, 161(June), 104982. doi:10.1016/j.resconrec.2020.104982

Lin, B., \& Ge, J. (2021). Does institutional freedom matter for global forest carbon sinks in the face of economic development disparity? China Economic Review, 65, 101563. doi:10.1016/j.chieco.2020.101563

Liu, S., Wilkes, A., Li, Y., Gao, Q., Wan, Y., Ma, X., \& Qin, X. (2016). Contribution of different sectors to developed countries' fulfillment of GHG emission reduction targets under the first commitment period of the Kyoto Protocol. Environmental Science \& Policy, 61, 143-153. doi:10.1016/j.envsci.2016.04.009

Maamoun, N. (2019). The Kyoto protocol: Empirical evidence of a hidden success. Journal of Environmental Economics and Management, 95, 227-256. doi:10.1016/j.jeem.2019.04.001

Mele, A., Paglialunga, E., \& Sforna, G. (2020). Climate cooperation from Kyoto to Paris: What can be learnt from the CDM experience? Socio-Economic Planning Sciences, (September), 100942.

Miyamoto, M., \& Takeuchi, K. (2019). Climate agreement and technology diffusion: Impact of the Kyoto Protocol on international patent applications for renewable energy technologies. Energy Policy, 129(February), 1331-1338. doi:10.1016/j.enpol.2019.02.053

Nguyen, J. H., \& Phan, H. V. (2020). Carbon risk and corporate capital structure. Journal of Corporate Finance, 64(August), 101713. doi:10.1016/j.jcorpfin.2020.101713

Nguyen, J. H., \& Shi, J. (2021). Are banks really special? Evidence from a natural experiment. Journal of International Financial Markets, Institutions and Money, 72.

Payne, R. A. (1995). Freedom and the Environment. Journal of Democracy, 6(3), 41-55.

Rahman, S. M., \& Kirkman, G. A. (2015). Costs of certified emission reductions under the Clean Development Mechanism of the Kyoto Protocol. Energy Economics, 47, 129-141. doi:10.1016/j.eneco.2014.10.020

Rios, V., \& Gianmoena, L. (2018). Convergence in CO2 emissions : A spatial economic analysis with crosscountry interactions. Energy Economics, 75, 222-238. doi:10.1016/j.eneco.2018.08.009

Shapiro, A. C., Grantham, H. S., Aguilar-Amuchastegui, N., Murray, N. J., Gond, V., Bonfils, D., \& Rickenbach, O. (2021). Forest condition in the Congo Basin for the assessment of ecosystem conservation status. Ecological Indicators, 122. 
Song, M., Xie, Q., Tan, K. H., \& Wang, J. (2020). A fair distribution and transfer mechanism of forest tourism benefits in China. China Economic Review, 63(August), 101542. doi:10.1016/j.chieco.2020.101542

Springer, U. (2003). The market for tradable GHG permits under the Kyoto Protocol: A survey of model studies. Energy Economics, 25(5), 527-551. doi:10.1016/S0140-9883(02)00103-2

Torras, M., \& Boyce, J. K. (1998). Income, inequality, and pollution: A reassessment of the environmental Kuznets Curve. Ecological Economics, 25(2), 147-160. doi:10.1016/S0921-8009(97)00177-8

van Vuuren, D. P., Cofala, J., Eerens, H. E., Oostenrijk, R., Heyes, C., Klimont, Z., den Elzen, M. G. J., \& Amann, M. (2006). Exploring the ancillary benefits of the Kyoto Protocol for air pollution in Europe. Energy Policy, 34(4), 444-460. doi:10.1016/j.enpol.2004.06.012 


\section{APPENDIX}

The first period includes 31 Annex B countries as the treated group, and 116 non-Annex B countries as the synthetic control group. The countries are shown in Table 8.

Table 8. The countries list of the first period

\begin{tabular}{|c|c|c|c|c|}
\hline Annex B countries & & Donor $p$ & ol countries & \\
\hline Australia & Angola & Egypt, Arab Rep. & Morocco & Singapore \\
\hline Austria & United Arab Emirates & Ethiopia & Moldova & Sierra Leone \\
\hline Belgium & Argentina & Fiji & Madagascar & El Salvador \\
\hline Canada & Antigua and Barbuda & Gabon & Maldives & Sao Tome and Principe \\
\hline Switzerland & Burundi & Georgia & Mexico & Suriname \\
\hline Denmark & Benin & Ghana & Mali & Eswatini \\
\hline Spain & Burkina Faso & Guinea & Myanmar & Seychelles \\
\hline Estonia & Bangladesh & Guinea-Bissau & Mongolia & Chad \\
\hline Finland & Bulgaria & Grenada & Mozambique & Togo \\
\hline France & Belarus & Guatemala & Mauritania & Thailand \\
\hline Greece & Belize & Guyana & Mauritius & Timor-Leste \\
\hline Croatia & Bolivia & Honduras & Malawi & Trinidad and Tobago \\
\hline Hungary & Brazil & Haiti & Malaysia & Tunisia \\
\hline Ireland & Bhutan & Indonesia & Namibia & Turkey \\
\hline Iceland & Botswana & India & Niger & Tanzania \\
\hline Italy & Chile & Iran, Islamic Rep. & Nigeria & Uganda \\
\hline Japan & China & Iraq & Nicaragua & Uruguay \\
\hline Lithuania & Cote d'Ivoire & Israel & Nepal & United States \\
\hline Luxembourg & Cameroon & Jamaica & Oman & Uzbekistan \\
\hline Latvia & Congo, Dem. Rep. & Jordan & Pakistan & Venezuela, RB \\
\hline Netherlands & Congo, Rep. & Kazakhstan & Panama & Vietnam \\
\hline Norway & Colombia & Kenya & Peru & Samoa \\
\hline New Zealand & Comoros & Kyrgyz Republic & Philippines & Yemen, Rep. \\
\hline Poland & Cabo Verde & Cambodia & Palau & South Africa \\
\hline Romania & Costa Rica & Korea, Rep. & Papua New Guinea & Zambia \\
\hline Russian Federation & Cuba & Lao PDR & Paraguay & Zimbabwe \\
\hline Slovakia & Cyprus & Lebanon & Rwanda & \\
\hline Slovenia & Dominican Republic & Liberia & Saudi Arabia & \\
\hline Sweden & Algeria & Sri Lanka & Sudan & \\
\hline Ukraine & Ecuador & Lesotho & Senegal & \\
\hline United Kingdom & & & & \\
\hline
\end{tabular}


There are a total of 140 countries in the second period, of which 113 countries are the synthetic control group, and the 27 Annex B countries are the treated group. The countries list is shown in Table 9.

\section{Table 9. The countries list of the second period}

\begin{tabular}{|c|c|c|c|c|}
\hline Annex B countries & & Donor $\mathbf{p}$ & ol countries & \\
\hline Australia & Angola & Ethiopia & Moldova & Singapore \\
\hline Austria & United Arab Emirates & Fiji & Madagascar & Sierra Leone \\
\hline Belgium & Argentina & Gabon & Maldives & El Salvador \\
\hline Switzerland & Antigua and Barbuda & Georgia & Mexico & Sao Tome and Principe \\
\hline Denmark & Burundi & Ghana & Mali & Suriname \\
\hline Spain & Benin & Guinea & Myanmar & Eswatini \\
\hline Estonia & Burkina Faso & Guinea-Bissau & Mongolia & Seychelles \\
\hline Finland & Bangladesh & Grenada & Mozambique & Chad \\
\hline France & Bulgaria & Guatemala & Mauritania & Togo \\
\hline Greece & Belize & Guyana & Mauritius & Thailand \\
\hline Croatia & Bolivia & Honduras & Malawi & Timor-Leste \\
\hline Hungary & Brazil & Haiti & Malaysia & Trinidad and Tobago \\
\hline Ireland & Bhutan & Indonesia & Namibia & Tunisia \\
\hline Iceland & Botswana & India & Niger & Turkey \\
\hline Italy & Chile & Iran, Islamic Rep. & Nigeria & Tanzania \\
\hline Lithuania & China & Iraq & Nicaragua & Uganda \\
\hline Luxembourg & Cote d'Ivoire & Israel & Nepal & Uruguay \\
\hline Latvia & Cameroon & Jamaica & Oman & United States \\
\hline Netherlands & Congo, Dem. Rep. & Jordan & Pakistan & Uzbekistan \\
\hline Norway & Congo, Rep. & Kenya & Panama & Venezuela, RB \\
\hline Poland & Colombia & Kyrgyz Republic & Peru & Vietnam \\
\hline Romania & Comoros & Cambodia & Philippines & Samoa \\
\hline Slovakia & Cabo Verde & Korea, Rep. & Palau & Yemen, Rep. \\
\hline Slovenia & Costa Rica & Lao PDR & Papua New Guinea & South Africa \\
\hline Sweden & Cuba & Lebanon & Paraguay & Zambia \\
\hline Ukraine & Dominican Republic & Liberia & Rwanda & Zimbabwe \\
\hline \multirow[t]{3}{*}{ United Kingdom } & Algeria & Sri Lanka & Saudi Arabia & \\
\hline & Ecuador & Lesotho & Sudan & \\
\hline & Egypt, Arab Rep. & Morocco & Senegal & \\
\hline
\end{tabular}


Jiamin Ge, Ph.D. candidate in Xiamen University, who has published 6 papers in SCI/SSCI journals.

Lin Boqiang obtained his BA degree in economics from Xiamen University and a Ph.D in economics from University of California at Santa Barbara. He was a principal energy economist of Asian Development Bank before he joined Xiamen University in 2006. He is currently a "Chang Jiang Scholar" Professor, Dean of China Institute for Studies in Energy Policy at Xiamen University; Vice Chairman of China Energy Society; Member of National Energy Consultation Committee under National Energy Commission; Member of National Energy Price Consultation Committee under National Development and Reform Commission; Member of Board of Directors and Chairman of Audit Committee of China National Petroleum Corporation; Special Analyst for China Xinhua News Agency; Guest Commentator for China National Radio. He is currently a member of the Energy Partnership Advisory Board and member of the Global Agenda Councils on Decarbonizing Energy of the World Economic Forum based in Davos Switzerland, and he was chairman of the Global Agenda Councils on energy security. He has published more than 350 academic papers on energy economics and energy policy (more than $300 \mathrm{SSCI} / \mathrm{SCI}$ papers (all are first author or correspondence author, or both), several energy economics textbooks and other books on energy policy (35 in total, in Chinese), about 800 column papers in most influential Chinese newspapers and about 200 short papers in Chinese main stream non-academic magazines. He has 19 awards on research and achievement in China. He has obtained funding for more than 100 research projects form the Chinese government departments, China national foundations, major energy companies, and international foundations. He has provided extensive support to the Chinese Government departments on energy reforms and energy strategy development. He is also an advisor to Ministry of Finance and People's Bank of China on energy issues. He has extensive media coverage on energy policy and energy issues in China. He is the corresponding author of this paper. 